\title{
From Gallipoli (1915) to the War of Independence (1919-1922): Modernisation of Turkish Womanhood
}

\author{
Burcu Cevik-Compiègne \\ University of Technology Sydney
}

\begin{abstract}
In many countries, the services of nurses during the First World War have recently been given a commemorative space in an attempt to make the memory of the war more inclusive and less masculine. In contrast, Turkish nurses' experience has so far been studied only from a nursing education and practice perspective. This article aims to shed light on this forgotten story by taking a gender and war studies perspective and reflect upon the much-celebrated memory of women fighters in Turkey.
\end{abstract}

\section{Introduction}

In Australia, when we think about the commemoration of women's war service, the first group of women that comes to mind is nurses. Although the recognition of the service of the nurses came late, they nevertheless took their place in the short list of those who deserve official recognition. The women who took what were traditionally considered as men's jobs or those who had to face all sorts of difficulties such as rape, displacement and privations due to the war do not seem to fit in any narrative of men going to the front to accomplish heroic deeds and women following them as their carers or waiting patiently at home. In Turkey, the remembrance of women's wartime experience is quite different. In the Ottoman Empire, nursing had, for a long time, been a male-only profession. In the $20^{\text {th }}$ century women started being introduced to the profession in order to provide care for female patients. After the Balkan Wars (1912-1913), the shortage of medical staff and the increasing contact with (c) 2014 Burcu Cevik-Compiègne. This is an Open Access article distributed under the terms of the Creative Commons Attribution 4.0 Unported (CC BY 4.0) License (https://creativecommons.org/licenses/by/4.0/), allowing third parties to copy and redistribute the material in any medium or format and to remix, transform, and build upon the material for any purpose, even commercially, provided the original work is properly cited and states its license.

Citation: Cosmopolitan Civil Societies Journal 2014, 6(3): 4206,- http://dx.doi.org/10.5130/ccs.v6i3.4206 
Western nurses and nursing education institutions brought change in the practice of female nursing (Bahçecik and Alpar 2009 p.699; Özaydın 2006 pp.163-4). In Gallipoli and the other campaigns of the First World War many women served as nurses and, although their work was greatly celebrated at the time, nurses are not remembered in Turkey now. The image of Turkish women which dominates the national iconography is that of women as warriors rather than that of women as nurses.

In the aftermath of the war, there was a tangible concern around the definition of Turkish national identity and there were very specific expectations from women in terms of nation building. The representation of women's war experience was crucial in defining their socalled national character. Although the modernisation of the nation, starting with women, seemed to be the main drive, the role model for Turkish women as a patriot warrior has still been largely embodied in the unsophisticated, uneducated and supposedly backward rural Anatolian woman. This complicates this idea of modernisation. While discussing the limits and the scope of the liberating effects of the wartime experience for Turkish women, this paper will also address the seeming juxtaposition of the modernity of urban women and the backwardness of peasant women.

\section{Women at war: 'an army of mothers and sisters' and labourers}

Women became particularly active in relief work during the Balkan Wars. There was a massive influx of Muslim refugees in Istanbul at the time and they needed food, clothing and health services. Several women's organisations and particularly the Women's Branch of the Red Crescent Society (RCS) took care of the fund raising and relief work. The Red Crescent Society also offered nursing classes for women over a period of five months and after a practical training a final examination was taken in order to obtain a diploma. From November 1914 to April 1915 alone, 300 women took the classes and 120 of them passed the exam (Tepekaya \& Kaplan 2003, p. 165). As well as the Red Crescent Society, certain hospitals also provided training for prospective nurses.

Making the nursing profession available to women was certainly a necessity in the context of the war but it was also perfectly in line with the idea of modernisation of the Tanzimat 
period $^{1}$. Similarly to Spivak’s assessment of Indian women’s position, Deniz Kandiyoti argued in the late 1980s, the 'position of women in the Ottoman polity was constituted as an ideological terrain' upon which the project of modernization was negotiated (Spivak 1993, p.102; Sirman 1988, n.p.). Forced to admit the material superiority of the West because of their colonial subjugation, Indian and Ottoman/Turkish nationalisms sought to protect their moral and spiritual values as the realm of Eastern superiority. The binary opposition of material and moral found its equivalents in world and home, public and private and man and woman (Chatterjee 1993, pp.120-1; Findley 1998, p23). While the discourse on modernity focused mainly on Westernization of the first category of each pairing, the latter was jealously protected as the signifier of national identity.

The Ottoman elite often qualified their society as 'backward', and the condition of women was also pointed at as an element of backwardness. It was argued that women should have access to education and knowledge in order to be able to give appropriate education to their children. Kandiyoti identifies the agenda of this male-sponsored reformation of women as ultimately liberating the younger generation of men from the oppressive patriarchal Ottoman family (Tekeli 2005, p.253). Therefore, woman’s modernization was not aimed at their liberation at all but simply towards access to education in order to perform their traditional duties in a way that met these new expectations within modern family structures. The nuclear family became the new norm, both establishing every head of the household as a figure of authority and preventing the moral decay that was associated with the collapse of traditional family structures. During the war period, family ceased to be a private affair and was regulated by diverse public agencies in order to ensure that women would not escape their reproductive duties (Toprak 1992, p.226). The example of the Islamic Society for Working Women (hereafter ISWW) illustrates how this policy was implemented.

The ISWW provided work for thousands of Muslim women in factories as well as in offices or other establishments depending on their skills. The aim of this society was not only to organize and promote work for women but also to give the activity of women official sanction (Ahmad 1988, p.280). On the other hand, the ISWW adopted the principle of compulsory marriage by the age of 20 for its female workers. The society took care of finding appropriate prospective grooms, or gave approval in cases where the young women

\footnotetext{
${ }^{1}$ Tanzimat literally means reformation. This period started in the 1839 with the introduction of European inspired laws and was interrupted with the reign of unpopular Abdulhamid II (1876-1908).
} 
designated their own future husbands. The carrot was a 20\% increase of wage for marriage and an additional 20\% for each child, the stick being a 15\% cut and subsequent dismissal from ISWW if women refused to get married by the age of 20 (Toprak 1992, p.225).

Therefore, women's work outside the home was accepted and even encouraged as an aspect of modernity as long as their activity did not threaten the modern and yet still patriarchal family structure. The nursing education program also fulfilled this requirement and therefore, it was met with support from the government and army as well as enthusiasm from the media.

Some of the women who worked in the Women's Branch of the Red Crescent Society also shared this ideal and described nursing education as a moral obligation for all women. Fatma Aliye, one of the prominent woman writers of the time and a founding member of the Women’s Branch said:

Women have practiced the art of nursing from time immemorial knowingly or unknowingly. Nursing has always, everywhere and in every household been a duty of women. In fact, nursing which is an important and difficult task is now bound by modern scientific principles. Caring for a patient while ignoring these principles may cause more damage than benefit. Since all women are endowed with qualities required for nursing and they are also morally responsible for this task they have to learn these principles (in Sarı \& Özaydın 1992, p.16).

Therefore, women were considered to be inherently inclined to patient care but this natural disposition was not enough anymore. They were also held morally responsible for developing their nursing skills further with formal education. This project of modernisation did not necessarily empower women and even women's ability to perform their traditional duties was questioned. Fatma Aliye continued:

Women suffered so many privations for so long, being taken for a flower or a doll, that let alone bandaging a wound, she would not stand seeing a little blood on a small cut and would pass out. In this situation, our ladies who go to bandage wounds are the heroes of our time. Holding an arm that is to be cut off, cleaning the wounds of a disintegrated hand and carrying out this duty with courage and calm, yes it qualifies as heroic (in Tepekaya \& Kaplan 2003, p.166).

Of course, the author, the subject and the addressee are all women who belong to an urban upper class and mostly are members of a bureaucratic elite. All women who were involved in the Red Crescent Society as well as most of those who took nursing classes came from the 
same urban elite. The condition of women described in their writings and their grievances are very specific to their social status as much as to their gender. These women had access to more than basic education and a good number of them studied further and excelled in a field, mostly in foreign languages and literature. Some of the women of this social background complained about the idleness of their daily lives and about not being able to put their knowledge to good use. During the Gallipoli campaign when hospitals were full and an increasing number of nurses were needed, the Women's Branch prepared publicity to encourage women to sign up to take classes in their spare time (Sarı \& Özaydın 1992, p.13). This notion of spare time and the desire to make contributions to society gave impulse to some of these women to become active in public life and the war gave them the opportunity. However, these activities did not defy the established gender order. They defined themselves as an 'army of sisters and mothers' and even the official papers of the Red Crescent Society defined them in relation to a male in their family (sister of $\mathrm{X}$, daughter of $\mathrm{Y}$, wife of $\mathrm{Z}$, and so on).

Not all women who were involved in these activities, however, were content with the description of their role as auxiliaries to men. Fatma Züleyha, who attended the classes in 1915, translated a nursing handbook from French because, she said, while she was studying there were no sources available in Turkish. She took special pride in translating this book that had been written in English by a woman (Miss Oxford) and also translated into French by another woman. In the preface of her publication she emphasized the role of nurses beyond its supposedly secondary nature. 'Without a scientifically trained nurse, a doctor will not get any results. Nursing is the acting hand of medicine [...]. The reason for the success of the surgical projects in Germany is the excellence of the nurses.' (Sarı \& Özaydın 1992, p.15). Clearly, Fatma Züleyha saw in the nursing profession something more than an extension of women's traditional duty and she meant to make a difference both as a nurse and as a translator.

There were also women from backgrounds other than this urban elite who were taken on in different circumstances. One of the reports of the Red Crescent Society, covering the period from 1912 to 1915, states that about 40 destitute Armenian women who immigrated to Kayseri were given room and boarding by the RCS and at the same time, they were offered nursing classes in an attempt to rehabilitate them. At the end of the mission in Kayseri, those who wished to go to Istanbul with the mission had their travel expenses paid (Sarı \& Özaydın 
1992, p.11). In Istanbul, it was possible for them to keep working as nurses. The same report represents RCS as the provider and these Armenian women as the beneficiaries of a charitable act. In so doing, it does not acknowledge the output of these nurses in the war effort. Nevertheless, it provides insight into how nursing education and practice may have significantly improved the condition of some poorer women. We do not know for sure what the social background of these Armenian women might have been. We can only speculate that a part of the stability that they lost because of the war may have been restored thanks to this new profession that was available to women, also because of the war.

Some women chose to join field hospitals and it seems that they even had a say in which front they would like to go to. In July 1915, a certain Fatma Servet who was working in Taksim Hospital in Istanbul obtained approval to join the war in Gallipoli as a wage-earning nurse (KA 221/43). Kerime Salahor, Safiye Hüseyin Elbi, Münire İsmail and Nesime Ahmed Dölen also volunteered to go to Gallipoli (Bahçecik \& Alpar 2009, p.700). This list may not be exhaustive and we do not know exactly how many women served as nurses in this campaign and what their experience was like. At least one female nurse named Erika died in service due to Allied bombing of the hospital behind the frontline, in the village of Yalova in Eceabat (Esenkaya 2011, p.59). She may not have received any posthumous honours but a number of women who volunteered to work in the hospitals in Istanbul were rewarded with medals (Tepekaya \& Kaplan 2003, p.164; Esenkaya 2011, p.59). In spite of official recognition and public encouragement at the time, the contribution of the nurses was soon to be forgotten ${ }^{2}$.

Nursing was not the only way for women to join the war. Some women from diverse backgrounds were engaged in the labour battalions. Formation of these women's battalions in 1918 was a necessity. Although many of the exemptions from military service had been revoked and the age of conscription had been extended to include males from 15 to 55 by 1916, high death tolls and desertion meant that the Army had to make the best of whatever workforce was available (Zürcher 1996, p.242). In February 1918, a call for enrolment was launched for robust women between 18-30 years of age, with good morals and character (to

\footnotetext{
${ }^{2}$ By contrast, male nurses’ experience was always disregarded. Male nurses served in much larger numbers throughout the war and although they were advantaged by lower eligibility requirements, they were sent to most dangerous posts. Undoubtedly, service in the ambulance corps was considered less honorable than bearing arms. Once women were introduced to the profession, the number of male nurses plummeted and in Turkish Republic nursing became a female-only profession until 2007.
} 
be certified by the local authorities) and without infant children. Single women were to stay in the barracks at all times whereas married women were allowed to spend four nights a week at their home, provided that they lived close enough to get back to work at a given time in the morning. Women in these battalions were to serve either as administrative clerks or labourers but after a while, all positions including the command and the administration of the battalion were left to women (Toprak 1992, pp.226-7). This decision seems to have been taken with a view to 'protecting the honour' of these women by reducing their hierarchical subordination to men.

The war opened up new possibilities to women and therefore this could be acknowledged as a time of progress. However the narrative of the War of Independence and the foundation of the Republic has been largely based on the association of the late Ottoman Period and especially the wartime Istanbul with moral decay, corruption and sexual promiscuity (Neumann 2006, pp.321-5). This representation contrasted with the image of the new nationstate leaders posing themselves as the enlightened saviours of Turkish women from the shackles of ignorance and subservience. Although the new regime shared the ideal for women's modernization with the Young Turk government of the Ottoman Empire, the leaders of the Republic rejected their heritage and continuity with the late Ottoman period. The achievements of the Turkish nurses along with other professional women during the war were thus buried in the pre-history of the Republic.

\section{Resistance and political activism}

Some urban women from upper classes, such as Halide Edip Adıvar, were also engaged in active resistance to the Allied occupation in the aftermath of the war. She was a prolific writer and a respected intellectual in nationalist circles. In March 1915, during the naval battle of Gallipoli, she attended secret meetings with other intellectuals, in order to coordinate a national resistance movement in case of the fall of Istanbul (Köroğlu 2010, pp.184-190); and she seemed to bring together a certain number of prominent nationalists and emerged as a de facto leader by the end of the war. After the occupation of Istanbul by the Allied forces in 1918, Halide Edip organized several protest rallies and the best known of these meetings took place on 19 May 1919 when she truly became a public figure by addressing a crowd of several thousands of people. She had, by then, become a seasoned orator but it was significant that it was the first time for a woman to deliver a speech on a public platform in a 
society where sexual segregation had only just started to dissipate. Many other women joined in the resistance against the foreign occupation and organized similar events throughout Anatolia (Tekeli 2005, p.259).

In fact, women had practiced political activism within women's branches of various organizations during the Balkan Wars. The scope of their activities during that time went beyond the frontiers. For instance, women from the Ottoman National Defence Organization had reached out to Indian women for support. Although there is no evidence that links the two events, almost simultaneously, a group of Muslim women from Calcutta organized a meeting in support of their Ottoman co-religionists and sent a resolution to the government (Özcan 1997, p.148). Pan-Islamic solidarity was the main feature of the Ottoman-Indian Muslim relations at the time and this was not particularly an original initiative. It is interesting, however, to note that this pan-Islamic solidarity signified not only an anticolonial struggle but also a fight to acquire a public voice for women in the face of the Islamic practice of gender segregation. Halide Edip reports that during her visit to India in 1936, letters she received from young Muslims (girls probably) all begged her to speak against purdah during her lectures ([Adıvar] 1938, p.52). However, as an observer Halide Edip was able to notice the range and the nuances of the attitudes to purdah among women and tackled with the topic sensibly.

An interesting comparison can be made between the Turkish and Indian Muslim women's wartime activities, because wartime political activities of Muslims of India were tightly linked to the events in Turkey. India saw an unprecedented mobilization of its Muslim population in support of the Ottoman Empire, which culminated in the Khilafat movement following the defeat of the Central Power. This period of turmoil was also an opportune moment for women to be involved in activities of public significance. Although they claimed the motivation of their activities was purely religious, in that particular context, religion and politics were inseparable. Thus, like the Turkish nurses, Indian Muslim women were able to extend their domestic responsibilities - in this case, safekeeping of the religious integrity - to the public sphere.

Another similarity between Turkish nurses and Indian Muslim women is the fact that these women were also related to the prominent male leaders of the time. They conducted their activities in parallel to their husbands'. The first Muslim woman who is reported to have ever 
addressed a mixed political gathering is Bi Amman, who spoke behind her veil at the annual meeting of Muslim League in 1917, on behalf of her son, Muhammad Ali, who was in prison. In 1921, she would speak lifting her veil this time and introducing herself as a mother figure to all present (Minault 1982, pp.252-4). Not only Muslims but also Hindu women such as Sarojini Naidu used the symbolism of the self-sacrificing mother, thus merging their political activities with the traditional responsibilities of women in order to obtain social acceptance. The limits of the socially acceptable shifted quickly and by the Indian Independence in 1947 women had taken up active roles in politics, although they were typically involved in women's organizations instead of taking part in the existing male-dominated parties (Forbes 1982, p.236).

Undoubtedly, the war affected Indian and Turkish women to very different degrees. The experience of armed conflict within the territory disturbed the sense of normality to a greater extent in Turkey. As discussed above, this opened up hitherto unseen possibilities to Turkish women who were, unlike their Indian counterparts, resolutely against sexual segregation at this point in time. Women were granted political rights soon after the foundation of the Turkish Republic. However, validating those rights in a male-dominated and authoritarian regime was another battle. Nezihe Muhiddin and her collaborators founded the first political party of the Republic, People's Party of Women, which was denied the right to run for the presidential campaign in 1927. The party was not even recognized as such and the leaders were advised to create an association instead (Tekeli 2005, pp.259-260).

Halide Edip, who participated in the creation of the Republic in so many ways, was also removed from the political scene during the early Republic. She had joined the resistance in Ankara and served with the armed forces throughout the War of Independence with the rank of Sergeant first and then Sergeant-Major. She did not really bear arms but worked as a translator; however she is sometimes referred to inaccurately as a woman fighter. After the independence, however, like many others who actively took part in the liberation, she was disappointed with Mustafa Kemal Atatürk’s authoritarian take on leadership. Halide Edip chose to leave Turkey in a self-imposed exile because she was unwilling to submit to the absolute authority of Mustafa Kemal who consequently labeled her a 'traitor’. She went back to Turkey shortly after his death and was elected to the parliament in the 1950s. In spite of her falling out with Atatürk, whose judgment is hardly ever questioned, she has been remembered respectfully and represented as the archetype of modern republican women. 


\section{Turkish women form an element of backwardness to the symbol of modernity}

The modernity that Halide Edip supported and expanded in her writings was a very complex one. During the war, she developed a strong mistrust for the Western world and rejected almost everything associated with it. Therefore, in her search for an indigenous model of modernity, she turned to rural Turkish women. Some other nationalists of the time were even more radical in their opposition to non-Turkish elements of identity. Nationalists such as Ziya Gökalp and Fatma Aliye blamed women’s conditions on Persian or Arab influences. According to this idea, sexual segregation, polygamy and woman's confinement in household had nothing to do with either Turkish tradition or Islam ([Yalman] 1930, p.234). Thus, the emerging Turkish nationalism found both its oriental 'Other' and the authentic 'Self'.

As discussed earlier, the Ottoman elite had internalized the European representations of their Empire as backward and thus they also internalized the system of values through which they were judged. It is, therefore, not surprising that they viewed their own subjects with the same lens through which they were regarded in Europe. As Ussama Makdisi put it, 'Ottoman reform created a notion of the pre-modern within the empire in a manner akin to the way European colonial administrators represented their colonial subjects' (2002, p.770). In Ottoman Orientalism, self definition was created in contrast with the Arabs as well as with the Turks of Anatolia. The major shift that occurred during the war was the identification of the Ottoman Muslim elite as Turkish, as opposed to Ottoman, which now connoted corruption and decay. Thus, Anatolian women were idealized as being authentic, simple, upright, hardworking, morally pure and self-reliant both by Halide Edip, who promoted a local Islamic mysticism, and those including Mustafa Kemal Atatürk, who looked back to a mythical past where Turkish society used to be egalitarian.

Celebration of the Anatolian female heroes who bore arms in provincial towns and villages also contributes to the myth of Turkish women as fierce fighters. Recently, a Turkish historian brought to light accounts of a few Anzac soldiers who told stories about women snipers some of whom were reportedly captured dead at Gallipoli (Tunçoku 2002). Although no official documents support the statements of those Anzac soldiers, some of whom were named and others of whom were anonymous, and Tunçoku himself is unable to affirm the veracity of these accounts, the article certainly propagated a strong belief in the existence of 
women fighters at Gallipoli. In the last few years, there has been an increasing number of web articles and pages dedicated to the celebration of those female heroes. An example is the story of Sergeant Halime who enlisted disguised in men's clothes (she was in fact, probably a transgender as she wore men's cloths and shaved her entire life). Another is the story of Corporal Nezahat who supposedly fought at Gallipoli as a child-soldier at only 8 alongside her father Col. Hafiz Halid Bey. Tens of other stories have been circulated and kindled the national zeal of a receptive public.

Depiction of Turkish peasant women as the carriers of ammunition and other supplies is also very common in the national celebration of women's contribution to the war effort. Given that these women usually appear with a baby in their arms and in traditional civilian clothes, their affiliation with any army troops would have been doubtful. That may be because it was not so rare that civilians spontaneously contributed to the war effort, particularly during the War of Independence after the First World War and the number of women labourers was not strictly limited to those who were recruited through official channels. However inaccurate it may be, the presence of a baby in that representation is very significant. Many of the stories that accompany these images (either in monuments, paintings or other media) relate the event of the death of the baby and the patriotic and dignified response of the mother. The message is that the sacredness of the nation prevails even over the sacredness of motherhood. In a country where the perceived constant threat of internal and external enemies translates into a readiness to fight and the militarisation of the entire society, this message is still relevant today. The mother who willingly offers the life of her child for the greater good of the country still stands as a role model for Turkish women.

This myth of the strong and self-reliant Turkish woman emphasizes manly characteristics and purposefully desexualizes and militarises women's identity. The suppression of femininity was certainly desired in order to decrease the discomfort of men in their social encounters with women, however there is more to it. Since the early Republic, Turkish girls are drilled to march in step usually three abreast, manoeuvre and stand to attention as part of their basic physical education, in order to maintain their readiness to fight in case of invasion. The underlying anxiety is obviously about rape in war. The fact that everybody knew at the time, and Halide Edip related in her novels and short stories, was that a tremendously bigger number of women went through the traumatic experience of rape than took up arms. The 
fantasy of Turkish women as fierce fighters operates as a coping mechanism, both acknowledging men's inability to protect them and the denial that the rape actually took place.

In fact, not only in the disputed areas, nor the places under occupation after the war, but also in other parts of current Turkey, rape was an everyday experience or a ubiquitous threat for many women. Mehmet Yavaş, a Gallipoli veteran said that when he came back from the war, he discovered that his wife had been kidnapped and he never saw her again (Önder 1981, p.57). In the Ottoman Army there was an extremely high rate of desertion. It was very common for these deserters to form armed gangs and take refuge in mountains or other

hideouts. They lived by carrying out raids and extortion and represented a danger particularly for women. Even after the war, some of them were not able to resume normal lives and some gangs had a surprising longevity. Rape by these gangs - let alone by the enemy - must have been so widespread that 'being taken to the mountain' became a synonym for 'being raped' in the Turkish language. Urban women also suffered sexual exploitation of a different sort. The number of prostitutes increased dramatically and segregated Muslim prostitution quarters were authorized for the first time during the war. Some 746 women were reported to have gone back to a regular activity after the war ([Yalman] 1930, p.244).

\section{Conclusion}

The war's impact on women depended as much on their social background as their gender. While an urban elite seized the war as an opportunity to become active in public, professional and political life through charities, nursing and political activism, poorer urban women who already worked outside of the house before the outbreak of the war had more and more trouble looking after their families. Although the absence of men provided them with some opportunities, the war economy destroyed almost all hope of earning a decent living. Women in rural areas and disputed areas were more vulnerable to rape and killings. The types of activities they were involved in did not change but they had a higher workload due to the absence of men. Some of them spontaneously fought against the enemy or contributed to the war effort however they could. But, as discussed above, their image as warriors was out of proportion and was created to fulfill the different agendas of the ideologues and the leaders of Turkish nationalism. Although gender roles were challenged to a certain extent, the evolution of the condition of women was fundamentally in line with pre-war policies. The war perhaps gave added pace to women's modernization process, which concerned and was led by mainly 
an urban population. The war also challenged the conceptualization of modernity. While the intended outward image was still Western, an idealized image of rural Anatolian women was posed as the spiritual model for all modern Turkish women. The story of Turkish nurses was written out of history in the process, because the earlier examples of social progress did not fit the narrative that the liberation of women was achieved under Atatürk’s reforms in a complete rupture with the Ottoman social policy.

\section{References}

KA 221/43 Kizilay Arsivi. Hastabakici Fatma Hanimin Gelibolu’ya istihdam edilmesi. [Adivar], H.E. 1938, Inside India, Macmillan, New York.

Ahmad, F. 1988, 'War and society under the Young Turks, 1908-18', Review, vol. 11, no. 2, pp. 265-86.

Bahçecik, N. \& Alpar, S. 2009, 'Nursing education in Turkey: From past to present', Nursing Education Today, vol. 29, pp. 698-703.doi: http://dx.doi.org/10.1016/j.nedt.2009.05.008

Chatterjee, P. 1993, Nation and Its Fragments: Colonial and Postcolonial Histories, Princeton University Press, Princeton.

Esenkaya, A. 2011, 'Çanakkale Muharebelerinde Cephede ve Cephe Dışında Sağlık Hizmetleri', Çanakkale Araştırmaları Türk Yıllı̆̆g, vol. 10-11, pp. 25-70.

Findley, C. 1998, 'An Ottoman Occidentalist in Europe: Ahmed Midhat meets Madame Gülnar, 1889', The American History Review, vol. 103, no. 1, pp. 15-49.doi: http://dx.doi.org/10.2307/2650772

Forbes, G.H. 1982, 'From purdah to politics: The social feminism of the All-India Women's Organizations', in Papanek, H. \& Minault, G. (eds.), Separate Worlds: Studies of Purdah in South Asia, Chanakya Publications, Delhi, pp. 219-44.

Köroğlu, E. 2010, Türk Edebiyatı ve Birinci Dünya Savaşı, 1914-1918: Propagandadan Milli Kimlik İnşasına, 2nd edition edn, İletişim, İstanbul.

Makdisi, U. 2002, 'Ottoman Orientalism', The American Historical Review, vol. 107, no. 3, pp. 768-96.doi: http://dx.doi.org/10.1086/532495

Minault, G. 1982, 'Purdah politics: The role of Muslim women in Indian Nationalism, 19111924', in Papanek, H. \& Minault, G. (eds.), Separate Worlds: studies of purdah in South Asia, Chanakya Publishers, Delhi, pp. 245-61. 
Neumann, C.K. 2006, 'The First World War as a time of moral failure: Its reflection in Turkish novels', in Farschid, O., Kropp, M. \& Dahne, S. (eds.), The First World War as remembered in the countries of the eastern Mediterranean, Orient-Institut, Beirut, pp. 321-8.

Önder, C. 1981, Doğumunun Yüzüncü Yılında Atatürk'ün Silah Arkadaşları: Yaşayan Çanakkaleli Muharipler, Akgün Form Ofset, Çan, Çanakkale.

Özaydin, Z. 2006, 'Upper social strata women in nursing in Turkey', Nursing History Review, vol. 14, pp. 161-74.doi: http://dx.doi.org/10.1891/1062-8061.14.161

Özcan, A. 1997, Pan-Islamism: Indian Muslims, the Ottomans and Britain (1877-1924), Brill, New York.

Sarı, N. \& Özaydın, Z. 1992, 'Dr. Besim Ömer Paşa ve Kadın Hastabakıcı Eğitiminin Nedenleri (I)', Sendrom, no. Nisan, pp. 10-8.

Sirman, N. December 1988 - May 1989, 'Turkish Feminism: A short History', Women Living Under Muslim Laws. Available at: http://www.wluml.org/fr/node/260 Accessed 17 February 2015.

Spivak, G.C. 1993, 'Can subaltern speak?', in Williams, P. \& Chrisman, L. (eds.), Colonial Discourse and Post-Colonial Theory: A Reader, Harvester Wheatsheaf, Hemel Hempstead, UK, pp. 66-111.

Tekeli, S. 2005, 'Les femmes : le genre mal-aimé de la République', in Vaner, S. (ed.), La Turquie, Fayard/CERI, Paris, pp. 251-81.

Tepekaya, M. \& Kaplan, L. 2003, 'Hilal-i Ahmer Kadınlar Cemiyeti'nin Kuruluşu ve Faaliyetleri ', Selçuk Üniversitesi Sosyal Bilimler Dergisi, vol. 10, pp. 147-201.

Toprak, Z. 1992, 'II. Meşrutiyet Döneminde Devlet, Aile ve Feminizm', in H.D. Yıldız (ed.), Sosyo-Kültürel Değişme Sürecinde Türk Ailesi, T.C. Başbakanlık Aile Araştırma Kurumu, Ankara.

Tunçoku, M. 2002, Çanakkale 1915: Buzdağının Altı, Türk Tarih Kurumu, Ankara.

[Yalman], A.E. 1930, Turkey in the World War, Yale University Press, New Haven.

Zürcher, E.J. 1996, 'Between Death and Desertion: The Experience of the Ottoman Soldier in World War I ', Turcica, vol. 28, pp. 235-58.doi:

http://dx.doi.org/10.2143/TURC.28.0.2004343 